\title{
Correction for global health and revenue effects of increased taxation of tobacco, Alcohol, and Sugar-Sweetened Beverages
}

Summan A, Stacey N, Birckmayer J, et al. The potential global gains in health and revenue from increased taxation of tobacco, alcohol and sugar-sweetened beverages: a modelling analysis. BMJ Glob Health 2020;5:e002143. doi: 10.1136/bmjgh-2019-002143.

The license type for this paper has changed from CC BY-NC to CC BY.

Open access This is an open access article distributed in accordance with the Creative Commons Attribution Non Commercial (CC BY-NC 4.0) license, which permits others to distribute, remix, adapt, build upon this work non-commercially, and license their derivative works on different terms, provided the original work is properly cited, appropriate credit is given, any changes made indicated, and the use is non-commercial. See: http://creativecommons.org/licenses/by-nc/4.0/.

(C) Author(s) (or their employer(s)) 2020. Re-use permitted under CC BY-NC. No commercial re-use. See rights and permissions. Published by BMJ.

BMJ Global Health 2020;5:e002143corr1. doi:10.1136/bmjgh-2019-002143corr1

A) Check for updates 